\title{
Results of a hydrogeological and hydrogeochemical study of a semi-arid karst aquifer in Tezbent plateau, Tebessa region, northeast of Algeria
}

\author{
Dalila Belfar $^{1} \cdot$ Chemseddine Fehdi $^{1,3} \cdot$ Fethi Baali $^{1} \cdot$ Elias Salameh $^{2}$
}

Received: 2 March 2013/Accepted: 13 October 2015/Published online: 31 October 2015

(C) The Author(s) 2015. This article is published with open access at Springerlink.com

\begin{abstract}
The Hammamet Plain, situated in the northwest of the Tezbent mountain range, northeast of Algeria, drains carbonate aquifers through some important karst springs. The physical and chemical characteristics of spring and well water samples were studied for 2 years to assess the origin of groundwater and determine the factors driving the geochemical composition. The ionic speciation and mineral dissolution/precipitation was calculated. Water wells, characterizing groundwater circulation at shallow depths, are moderate to high mineralized waters of $\mathrm{Na}-\mathrm{HCO}_{3}$ type. In contrast to the shallow environment, the $\mathrm{CO}_{2}$-rich, deeper waters are of the $\mathrm{Ca}-\mathrm{HCO}_{3}-\mathrm{SO}_{4}$ type and undergo significant changes in the baseline chemistry along flow lines with increasing residence time. The main factors controlling the groundwater composition and its seasonal variations are the geology, because of the presence of carbonate formations, the elevation and the rate of karst development. In both groups, the carbonate chemistry is diagnostic of the effect of karst development. The supersaturation with respect to calcite indicates $\mathrm{CO}_{2}$ degassing, occurring either inside the aquifer in open conduits, or at the outlet in reservoirs. The undersaturation with respect to calcite shows the existence of fast flow and short residence time conditions inside the aquifer. Interaction between groundwater and surrounding host rocks is believed to be
\end{abstract}

Chemseddine Fehdi

fehdi@yahoo.fr

1 Laboratory Water and Environment, Department of Geology, Tébessa University, 12002 Tébessa, Algeria

2 Department of Geology, University of Jordan, Amman, Jordan

3 Route de Annaba Nº71, 12000 Tébessa, Algeria the main process responsible for the observed chemical characteristics of groundwater in the study area.

Keywords Karst aquifer - Hydrochemistry - Saturation indices $\cdot$ Tezbent $\cdot$ Algeria

\section{Introduction}

Water stored in karst aquifers represents an important source of drinking water in many countries around the world where the importance of water quality in human health has recently attracted a great deal of interest. In the developing world, $80 \%$ of all diseases are directly related to poor drinking water and unsanitary conditions (Olajire and Imeokparia 2001).These aquifers are also used for irrigation. For all these reasons, water resources must be managed in a sustainable way (Bakalowicz 2005). Since the signification of karst aquifers as important water resource and valuable ecosystems is growing worldwide, these hydrological systems are receiving rapidly increasing attention from the scientific, engineering and regulatory communities. Due to the many challenges related to their characterization and management, such aquifers require good knowledge and comprehension of groundwater characteristics (Goldscheider and Drew 2007; Bonacci et al. 2009). One of the advantages of bigger karst springs is sufficient amounts of water also during the time of low waters. On the other hand, these springs have large catchments and their effective protection against pollution is a great challenge. As a result, water quality of these springs is often not good (Ravbar and Kova 2006). The study area lies in the semi-arid region of Algeria and is susceptible to the various threats common in both growing urban areas and developing agricultural areas. The Tezbent 
plateau and the surrounding villages (Chéria, Hammamet) have seen a great deal of growth in the past decade, with the establishment of new industries and farms (Rouabhia et al. 2009). It is situated $20 \mathrm{~km}$ far from Tebessa city. It extents on about $160 \mathrm{~km}^{2}$ and is characterized by a precipitation of $<300 \mathrm{~mm} / \mathrm{year}$ (Fig. 1).

The present investigation concerns the whole Tezbent plateau. The main objectives are the identification of the hydrogeological and hydrogeochemical processes that are responsible for the groundwater quality.

\section{Geological and hydrogeological description of the study area}

The study area is a part of the Oriental Saharan Atlas near Algerian-Tunisian borders and precisely constitutes a part of the Mellegue Mountains. The stratigraphic characteristics marking the study area show a diversity of facies predominantly limestone, marly limestone, dolomitic limestone and marl, these formations are thick and rich in fossils (Fig. 2).

Strong fracturing and the predominance of limestone and marly limestones alternating in series have greatly contributed to the acceleration of erosion and the product of this destruction would be an ideal host rock aquifer.

The Eocene limestone formations, which are about $100 \mathrm{~m}$ thick in the study area (Fig. 3), constitute a limited aquifer. The dense and thick bedded limestone in the Djebel Tezbent has numerous joints and fractures. The karst phenomenon seems to be limited to some solution features and small shelter caves. Contrary to the Eocene limestone, Maestrichian carbonate formation, which is the main aquifer (about $300 \mathrm{~m}$ thick), some deep caves are known and the existence of some very important springs, with mean flow rates up to $3,300 \mathrm{l} / \mathrm{s}$, indicates that karst developed in the carbonate aquifers to some degree. In a first approach, all the carbonate aquifers may be considered as being karstic. Generally, the Eocene limestone formations and Maestrichian carbonate are hydraulically disconnected in most parts of the synclines, since the existence of the impermeable marly formations under the Tezbent mountain is higher than the adjacent overlying formations.

The Plio-Quaternary formations host a shallow aquifer with a local importance. It consists of alluvial sediments, gravels, silts, calcretes, and lacustrine limestone (Vila 1980), containing an unconfined aquifer. This aquifer plays a very important role in supplying drinking water to the local population. Overexploitation of this resource has caused a progressive degradation of the water quality in the irrigated area with the occurrence of high salinity zones which create problems of water use.

\section{Methodology}

\section{Sampling and analysis}

Groundwater samples were collected for geochemical analysis at different depths from six production wells penetrating the shallow aquifer and four springs (Fig. 2). The temperature, conductivity and $\mathrm{pH}$ were measured in the field. Electrical conductivity and water temperature were measured using an Orion 240 conductivity meter and prob. $\mathrm{pH}$ was measured using Orion $250 \mathrm{pH}$-meter regularly calibrated using two standard buffers.

Chemical analyses were undertaken at the Hydrochemistry Laboratory of Tébessa University. Major cation

Fig. 1 Location of the study area

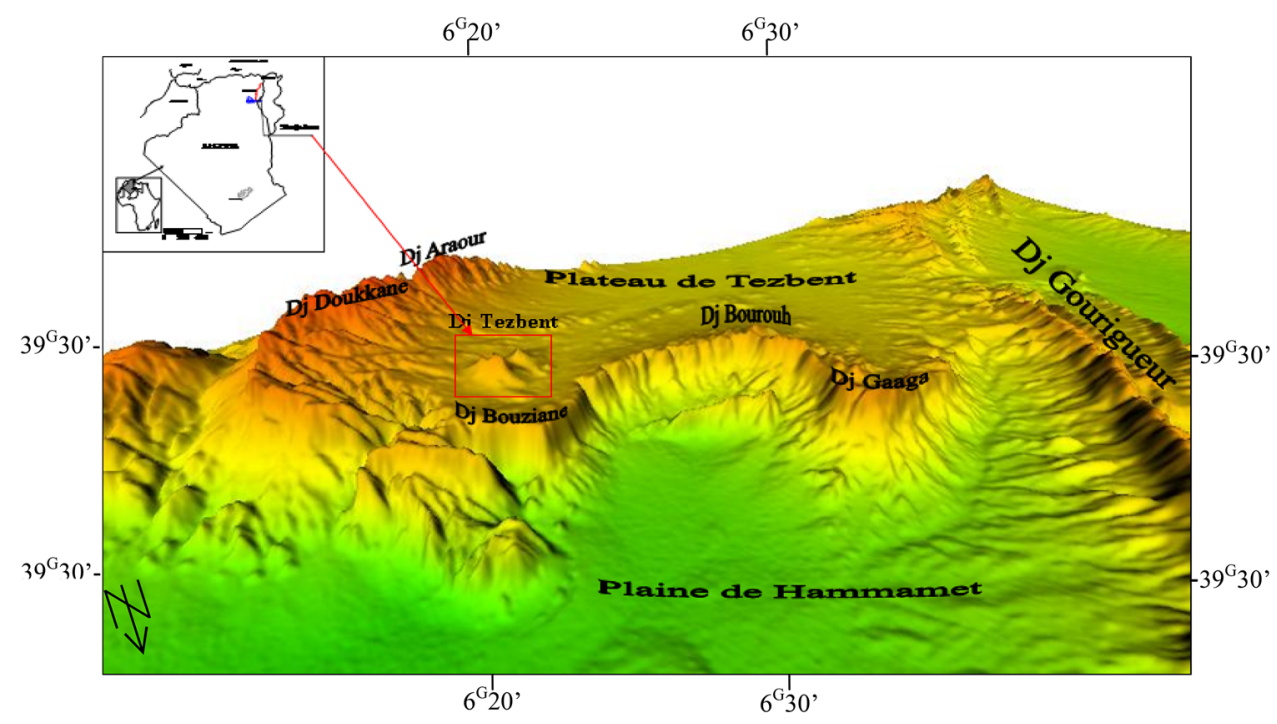


Fig. 2 Geology of the studied area

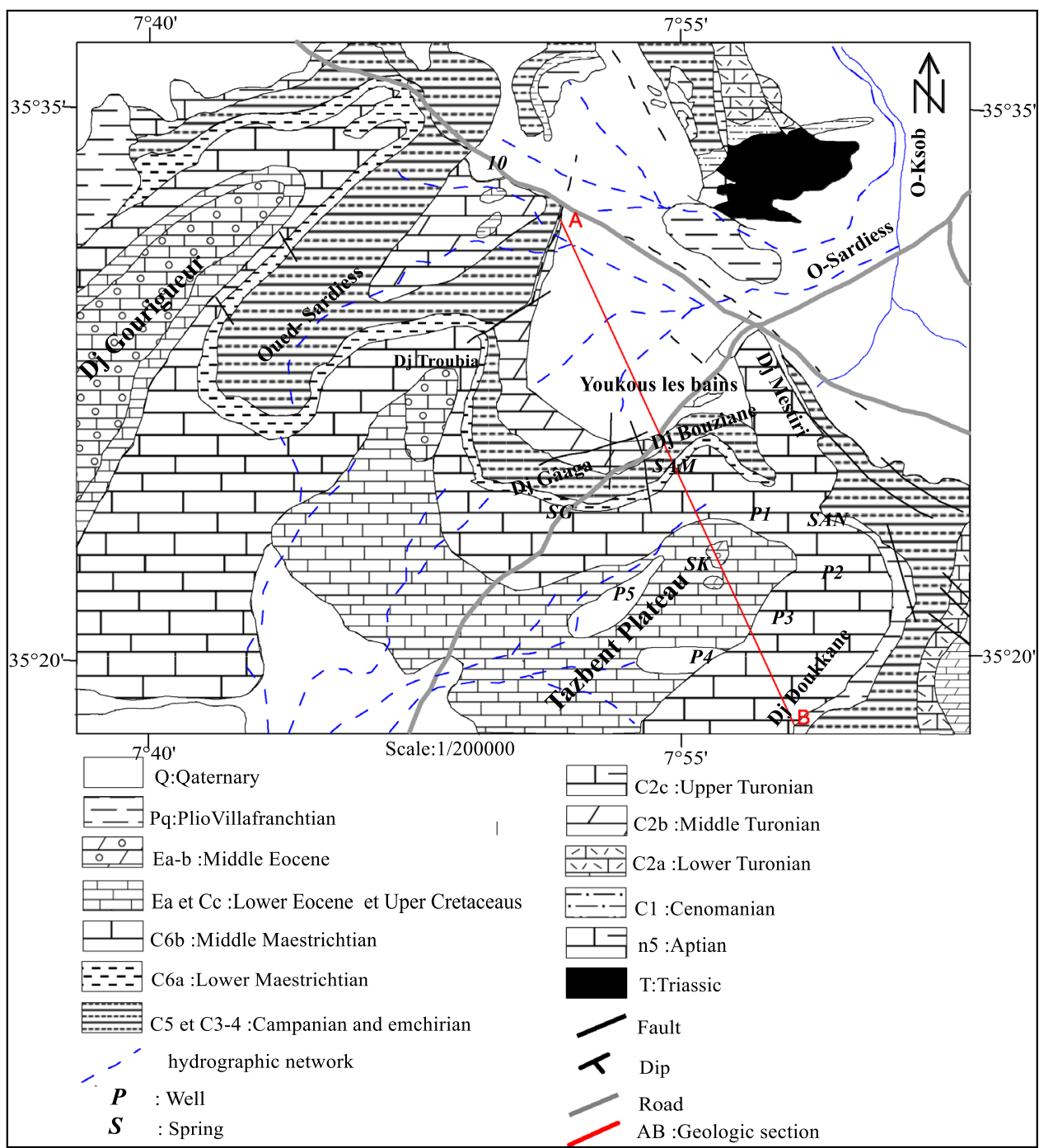

N.NW
Dj Doukkane

Dj Tazbent

Dj Bouziane O.Bililia SAK O.El Hassa

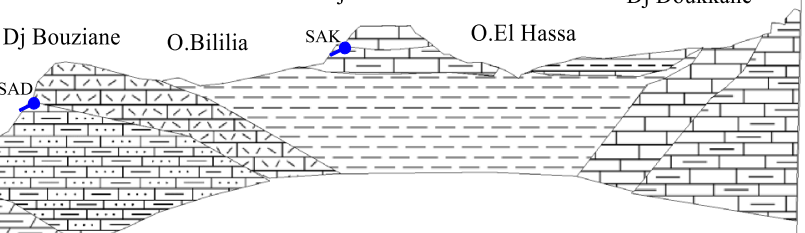

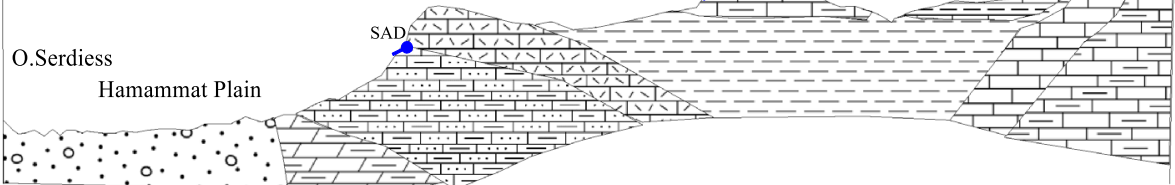

$2 \mathrm{Km}$

$\because \because \because$ Qaternary

Middle and Lower Eocene

L- Lower Eocene and Cretaceous (Marle)

$\triangle \backslash$ Middle Maestrichtian

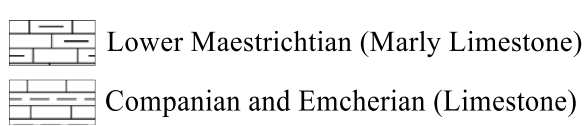

- Spring

1 
concentrations $\left(\mathrm{Ca}^{2+}, \mathrm{Mg}^{2+}, \mathrm{Na}^{+}\right.$and $\left.\mathrm{K}^{+}\right)$together with $\mathrm{PO}_{4}{ }^{3-}$ were determined using atomic adsorption spectrophotometry. Calibrations for cation analyses were performed using appropriately diluted standards, and both laboratory and international reference materials were used as checks for accuracy.

The analysis of bicarbonate was undertaken by titration to the methyl orange endpoint. Concentration of chloride was determined by titration and precipitation of $\mathrm{AgCl}$ until silver chromate appears. Sulfate was determined by precipitation of $\mathrm{BaSO}_{4}$ and then measuring the absorbency with a spectrophotometer.

\section{Results and discussion}

Understanding the groundwater quality is important as it is the main factor determining its suitability for drinking, domestic, agricultural, and industrial purposes (Fehdi et al. 2008). The chemical composition of the water samples collected from the study area is given in (Table 1).

\section{Groundwater chemistry}

The different water samples have been classified according to their chemical composition using the Piper diagram (Piper 1944). This classification is based on the concentration of the four major anions bicarbonate, sulfate, chloride and nitrate and on the four major cations sodium, potassium, calcium and magnesium.

Using the software Diagrammes (Simler 2004), water samples of the study aquifer system are plotted on a Piper diagram (Fig. 4) and Scholler-Berkaloff diagram (Fig. 5) to make a comparison between the different water types and to show the effect of mixing between water. The Piper diagram shows that the overall chemical character falls within the following water types:

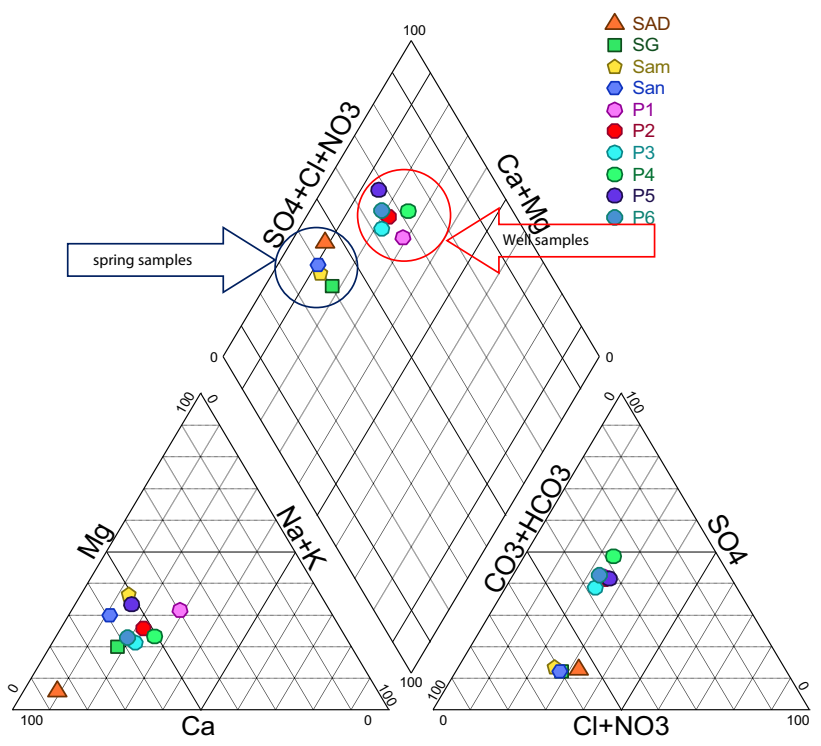

Fig. 4 Piper trilinear diagram of water chemistry in the study area

- moderate to high mineralized waters of $\mathrm{Na}-\mathrm{HCO}_{3}$ type

- deeper waters of the $\mathrm{Ca}-\mathrm{HCO}_{3}-\mathrm{SO}_{4}$ type.

The first water type changed continuously due to the influence of many factors:

First, the water-rock interaction of the aquifer material with mainly carbonates facies and secondly, the influence of human activities such as irrigation returns flow and overexploitation of the aquifer system. The result is indicated by a rapid increase in sodium, sulfate and chloride concentrations in the aquifer. By following the direction of groundwater flow, the water changes its chemistry and becomes more saline, whereby the high sodium concentration is usually an indication of cation-exchange process.

\section{Water-rock interaction process}

Interactions between groundwater and surrounding host rocks are mostly the main processes responsible for the

Table 1 Chemical composition (in $\mathrm{mg}^{-1}$ ) of groundwater from the study area

\begin{tabular}{lcclllllllccc}
\hline Samples & $\mathrm{pH}$ & $\mathrm{TDS}$ & $\mathrm{NO}_{3}{ }^{-}$ & $\mathrm{HCO}_{3}$ & $\mathrm{SO}_{4}{ }^{2-}$ & $\mathrm{Cl}^{-}$ & $\mathrm{Na}^{+}$ & $\mathrm{K}^{+}$ & $\mathrm{Mg}^{2+}$ & $\mathrm{Ca}^{2+}$ & $\mathrm{PO}_{4}{ }^{2-}$ \\
\hline SAD & 7.9 & 407 & 5.2 & 194.3 & 35.25 & 63.9 & 80.0 & 5.7 & 8.34 & 89.72 & 1.7 \\
SG & 7.8 & 461 & 6.1 & 251.5 & 40.0 & 65.7 & 15.5 & 8.3 & 11.19 & 60.92 & 1.9 \\
SAM & 7.9 & 543 & 8.8 & 283.0 & 49.01 & 73.2 & 18.3 & 9.0 & 33.38 & 77.33 & 1.4 \\
SAN & 8.1 & 481 & 5.6 & 243.0 & 38.22 & 62.46 & 16.3 & 7.43 & 25.6 & 82.55 & 2.1 \\
P1 & 7.2 & 784 & 3.6 & 212 & 110.0 & 88.9 & 88.0 & 10.62 & 54.9 & 112.2 & 3.7 \\
P2 & 7.3 & 796 & 7.5 & 209 & 102.3 & 84.98 & 72.3 & 11.6 & 48.55 & 162.09 & 0.3 \\
P3 & 7.4 & 758 & 4.3 & 223 & 160.8 & 79.3 & 65.4 & 8.6 & 35.7 & 157.1 & 4.8 \\
P4 & 7.1 & 815 & 8.6 & 211.3 & 190.0 & 99.5 & 60.2 & 5.34 & 29.6 & 106.03 & 3.2 \\
P5 & 7.0 & 1,158 & 6.0 & 305.23 & 205.6 & 139.9 & 71.34 & 6.91 & 67.7 & 184.52 & 3.8 \\
P6 & 7.2 & 855 & 7.0 & 248.6 & 180.9 & 91.69 & 57.2 & 7.6 & 39.31 & 163.23 & 0.7 \\
\hline
\end{tabular}


Fig. 5 Scholler-Berkaloff diagram of groundwater samples in the study area

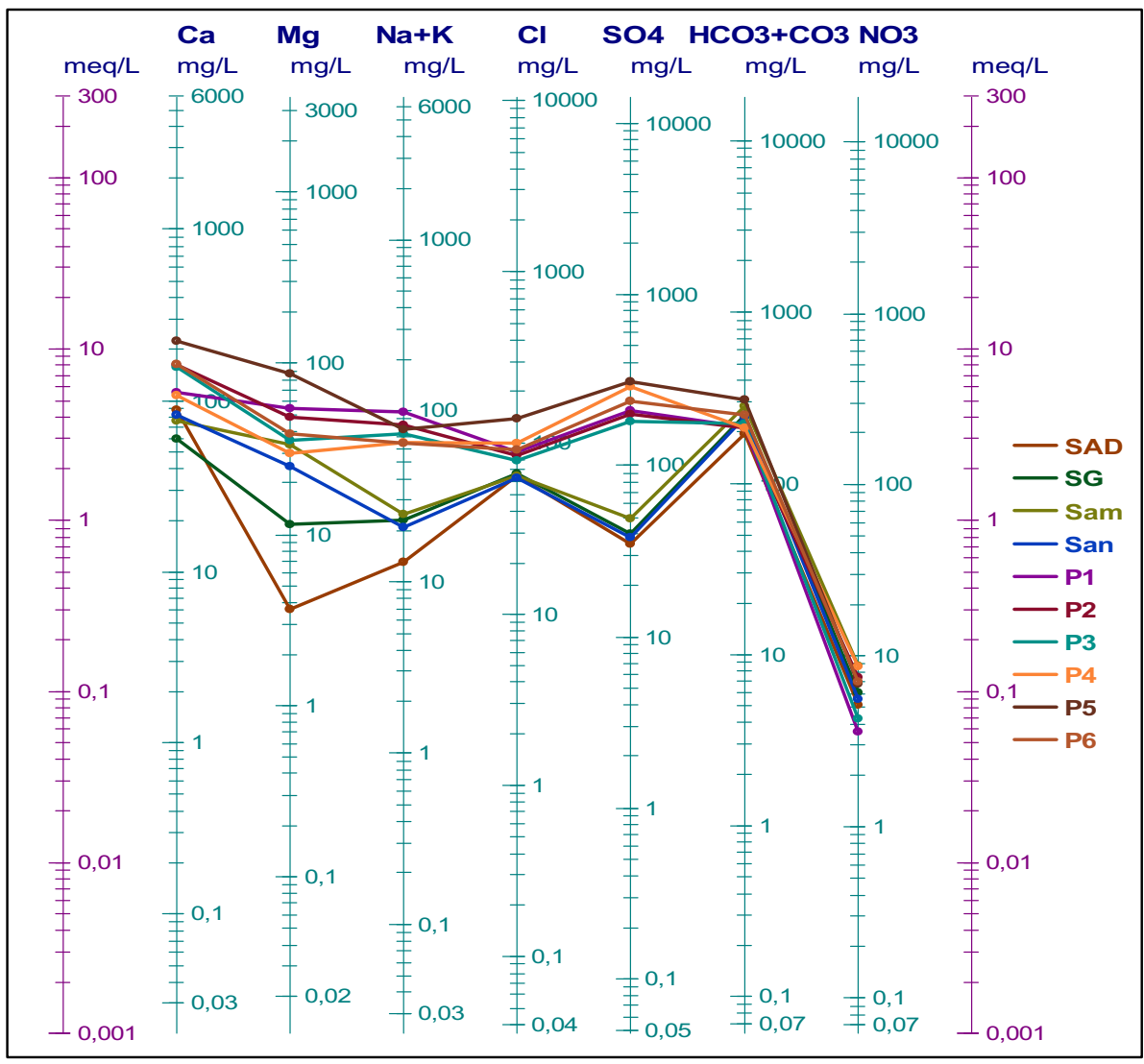

observed chemical characteristics of groundwaters in the study area (Rouabhia et al. 2009). Evaluation of such processes requires the description of the mean mineral assemblage of the rocks in which water is found, and the identification of the chemical reactions responsible for the geochemical evolution of groundwaters (Salameh 2001). From available studies in the literature, such reactions generally include chemical weathering of rock-forming minerals, dissolution-precipitation of secondary carbonates and ion exchange between water and clay minerals.

Two approaches, mathematical and graphical, are generally used for the resolution of hydrogeochemical problems. The mathematical approach is often used for the calculation of saturation indices with respect to mineral phases, thus providing some indication upon the equilibrium state between groundwater and surrounding minerals rock assemblage.

In this present paper, different parameters calculated based on the chemical analyses of the water samples include $\mathrm{pH}$-equilibrium, $\mathrm{PCO}_{2}$, ionic strength and saturation indices for calcite, aragonite, dolomite, gypsum, and anhydrite.

Saturation indices express the extent of chemical equilibrium between water and mineral phases in the matrix of the aquifers and could be regarded as a measure of dissolution and/or precipitation processes relating to the waterrock interaction.
The degree of saturation can be evaluated according to the following equation:

$\mathrm{SI}=\log \left(K_{\mathrm{IAP}} / K_{\mathrm{sp}}\right)$.

$K_{\text {IAP }}$ The ionic activity product of the ions.

$K_{\text {sp }} \quad$ The solubility product of the mineral.

SI The saturation indices.

If $\mathrm{SI}<0$. The water is undersaturated with respect to a certain mineral which means that the water is still able to dissolve that specific mineral.

If $\mathrm{SI}>0$. The water is oversaturated with respect to that mineral and the mineral will precipitate.

If $\mathrm{SI}=0$. Water is in equilibrium.

The computer geochemical program PHREEQC-2 version 2.10 (Appelo et al. 1999) was used to calculate the ionic speciation of the waters, the ionic activities, the theoretical $\mathrm{PCO}_{2}$ and most importantly, the saturation indices of calcite, aragonite, dolomite, gypsum, and anhydrite. The significant results are that all the groundwater samples were found to be saturated with respect to calcite, dolomite, and aragonite but undersaturated with respect to gypsum and anhydrite (Table 2).

Figure 6 shows the distribution of the computed $\mathrm{PCO}_{2}$ values for all samples. These values vary between -2.227 
Table 2 Saturation indices of groundwater samples

\begin{tabular}{lrllll}
\hline $\begin{array}{l}\text { Groundwater } \\
\text { samples }\end{array}$ & $\begin{array}{l}\text { SI } \\
\text { calcite }\end{array}$ & $\begin{array}{l}\text { SI } \\
\text { aragonite }\end{array}$ & $\begin{array}{l}\text { SI } \\
\text { dolomite }\end{array}$ & $\begin{array}{l}\text { SI } \\
\text { gypsum }\end{array}$ & $\begin{array}{l}\text { SI } \\
\text { anhydrite }\end{array}$ \\
\hline SAD & 0.32 & 0.17 & -0.95 & -1.79 & -2.01 \\
SG & 0.22 & 0.07 & -0.48 & -1.90 & -2.12 \\
SAM & 0.22 & 0.07 & -0.13 & -1.74 & -1.96 \\
SAN & 0.30 & 0.15 & -0.12 & -1.81 & -2.03 \\
P1 & 0.12 & -0.02 & -0.27 & -1.01 & -1.23 \\
P2 & 0.21 & -0.35 & -1.14 & -0.88 & -1.10 \\
P3 & 0.03 & -0.13 & -0.82 & -0.93 & -1.15 \\
P4 & -0.06 & -0.20 & -0.87 & -0.89 & -1.11 \\
P5 & 0.29 & 0.14 & -0.03 & -0.61 & -0.83 \\
P6 & -0.12 & -0.27 & -1.07 & -0.80 & -1.02 \\
\hline
\end{tabular}

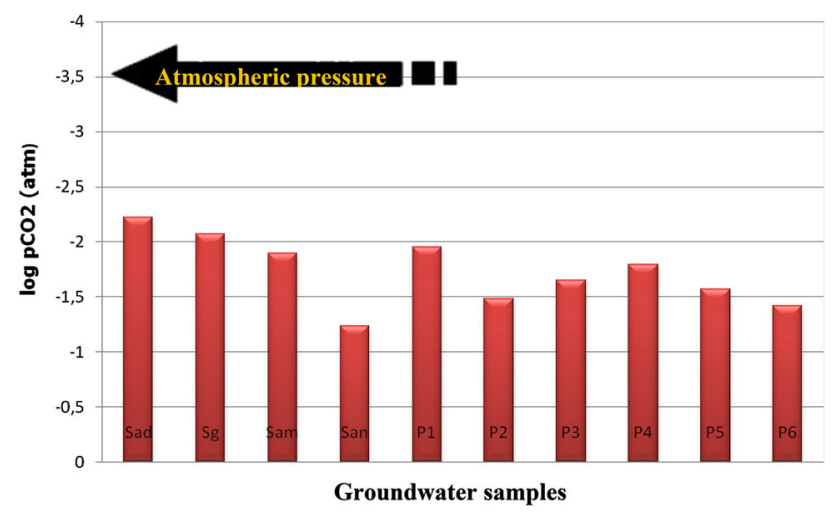

Fig. 6 Distribution of equilibrium partial pressure of $\mathrm{CO}_{2}$ (on $\log$ scale) as computed with PHREEQC-2

and -1.233 being significantly higher than that of atmosphere $\left(10^{-3.5}\right)$ atm. Such elevated values suggest that the groundwater system is open to soil $\mathrm{CO}_{2}$. The source of dissolved $\mathrm{CO}_{2}$ can be determinate on the basis of ${ }^{13} \mathrm{C}$ analyses (anthropogenic and biogenic origin).

In the diagram ISC/ISD (Fig. 7), the representative points of the water samples are aligned generally along a regression line whose Eq. (1) is:

$\mathrm{ISD}=1.6269 \mathrm{ISC}-0.768$

Most of the water samples are over saturated with respect to calcite (ISC $>0$ ) and under saturated with respect to dolomite ISD $<0$ with the exception of three water samples where ISC and ISD are negative. These wells are: P2 $(\mathrm{ISC}=-1.14 ; \quad$ ISD $=-0.21), \quad$ P4 $\quad(\mathrm{ISC}=-0.87$; ISD $=-0.06$ ), P6 (ISC $=-1.07$; ISD $=-0.12$ ).

The waters of the study area were divided into two groups according to the values of ISD.

1. Family 1 (ISD > -0.5) it covers five water samples (SG, SAM, SAN, well 01, and well 05). These waters have saturation indices of calcite and dolomite very close to equilibrium state.

2. Family $2(I S D<-0.5)$ the values of saturation indices reflect an under saturation state with respect to dolomite and an over saturation with respect to calcite significantly stronger as compared to the Family 1.

\section{Conclusion}

In the present study, the sampled springs and wells in the plateau of Tezbent were characterized in terms of hydrogeological and hydrogeochemical compositions and the conceptual underground flow systems were proposed. Water wells, characterizing groundwater circulation at shallow depths, are moderate to high mineralized waters of
Fig. 7 Diagram ISDolomite/ ISCalcite of water wells and springs in the area of Tezbent

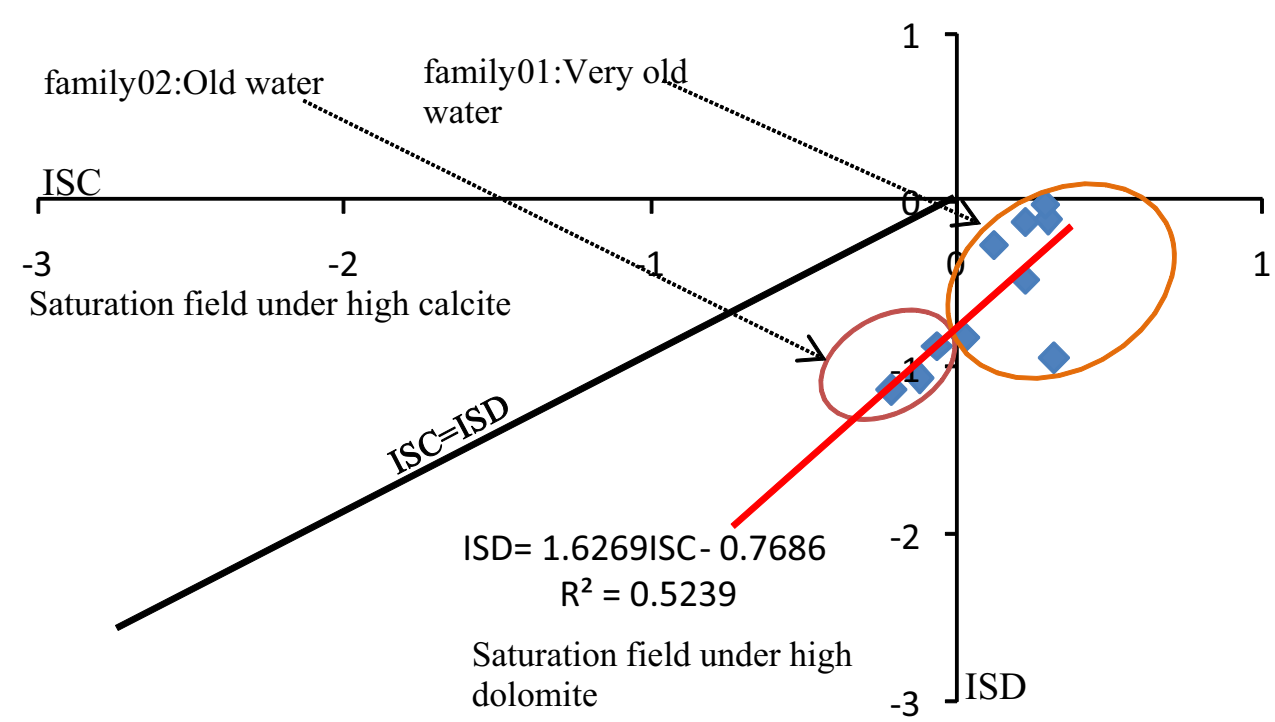


$\mathrm{Na}-\mathrm{HCO}_{3}$ type. In contrast to the shallow environment, the $\mathrm{CO}_{2}$-rich, deeper waters are of the $\mathrm{Ca}-\mathrm{HCO}_{3}-\mathrm{SO}_{4}$ type and undergo significant changes in the baseline chemistry along flow lines with increasing residence time.

Two hydrogeological systems were defined in the study area: (1) a deep water system, which is related to extensive and deep circulation of meteoric water in the regional flow system where the influence of shallow waters is relatively small, and (2) a shallow system, which is related to shallow circulation, and is affected very rapidly by recent rainfall events.

The ionic speciation and mineral dissolution/precipitation were calculated. The significant results are that all the groundwater samples were found to be saturated with respect to calcite, dolomite, and aragonite but undersaturated with respect to gypsum and anhydrite.

Acknowledgments The authors acknowledge the co-operation of Laboratoire Eau et Environnement de l'Université de Tébessa, for their participation in some of the analytical programmes. Authors wish to give special thanks to Prof. Elias Salameh of Jordan University, Department of Geology.

Open Access This article is distributed under the terms of the Creative Commons Attribution 4.0 International License (http:// creativecommons.org/licenses/by/4.0/), which permits unrestricted use, distribution, and reproduction in any medium, provided you give appropriate credit to the original author(s) and the source, provide a link to the Creative Commons license, and indicate if changes were made.

\section{References}

Appelo C, Williemsen A, Beekmanhe Grippioen (1999) Calculations and observations on salt water intrusion, II. Validation of a geochemical model with laboratory experiments. J Hydrol 120:225-250

Bakalowicz M (2005) Karst groundwater: a challenge for new resources. J Hydrol 13:148-160

Bonacci O, Pipan T, Culver DC (2009) A framework for karst ecohydrology. Environ Geol 56:891-900

Fehdi Ch, Rouabhia Aek, Baali F (2008) The hydrogeochemical characterization of Morsott-El Aouinet aquifer, Northeastern Algeria. Environmental geology. Springer, Berlin. doi:10.1007/ s00254-008-1667-4

Goldscheider N, Drew D (2007) Methods in karst hydrogeology. Taylor \& Francis, London, p 264

Olajire AA, Imeokparia FE (2001) Water quality assessment of Osun river: studies on inorganic nutrients. Environ Monit Assess 69(1):17-28

Piper AM (1944) A graphic procedure in geochemical interpretation of water analysis. Trans Am Geophys Union 25(6):914-928

Ravbar N, Kova G (2006) Karst water management in Slovenia in the frame of vulnerability mapping. Acta Carsol 35(2):73-82

Rouabhia Aek, Baali F, Fehdi Ch (2009) Impact of agricultural activity and lithology on groundwater quality in the Merdja area, Tebessa, Algeria. Arab J Geosci. Springer, Berlin. doi:10.1007/ 12517-009-0087-4

Salameh E (2001) Sources of water salinities in the Jordan Valley Area, Jordan. Acta Hydrochim Hydrobiol 6-7:329-362

Simler R (2004) Logiciel d'hydrochimie multilangage en distribution libre. Laboratoire d'Hydrogéologie d'Avignon, Version 2

Vila JM (1980) La chaîne alpine de l'Algérie orientale et des confins Algéro-Tunisiens. Thèse de Doctorat- es -sciences, Université Pierre et Marie Curie, Paris VI 